\title{
Seramik Sanatında Suyun İzi
}

\section{Dr. Yasemin Tanriverdi ${ }^{*}$}

Geliș tarihi: 29.12.2019

Kabul tarihi: 29.01.2020

\section{Atıf bilgisi:}

IBAD Sosyal Bilimler Dergisi

Sayı: $6 \quad$ Sayfa: $390-408$

Yıl: 2020 Dönem: Kış

This article was checked by iThenticate. Similarity Index 4\%

Bu makalede araștırma ve yayın etiğine uyulmuştur.

1 Mimar Sinan Üniversitesi, Türkiye, yasem.t5@gmail.com

ORCID ID 0000-0002-6869-4454

\section{öz}

$\mathrm{Su}$, yaşamsal önemi ile insanlık tarihindeki en temel unsurlar arasında yer almaktadır. Seramiğin temel malzemesi olan toprak ise, su aracilığı ile hayat bulmaktadır. Dünya üzerinde geniş bir yer kaplayan su, sanat alanında önemli bir imgedir. Hemen hemen bütün dinlerde su arınmayı temsil etmektedir. İçerisinde zıtlıkları barındıran su, aynı zamanda toplumlar için yaşam ve ölümün imgesidir. İnsan yaşamında önemli yere sahip olan su imgesi, birçok sanatçııın da eserlerinin çıkış noktası olmuştur. Sanatçıların eserlerinde su imgesini ele alış biçimleri farklılıklar göstermektedir. Bellekle kurulan ilişkiye göre su imgesi eserlerde bazen suyun bıraktığı izle, bazen temsil ettiği suyun şekliyle, bazen de suyu içerisinde barındıran form olarak karşımıza çıkmaktadır. Bu çalışmada kültürler üzerindeki "su" imgesi araştırılmış, sanatçıların bu imgeyi hangi şekillerde kullandığı incelenmiştir. Söz konusu imgenin bellekle kurulan ilişkide seramik sanatçılarının eserlerindeki yansımaları belirtilmiştir.

Anahtar Kelimeler: Su, İmge, Seramik Sanatı, Bellek, Kültür.

\section{* Sorumlu yazar}




\section{Trace of Water in Ceramic Art}

\section{Dr. Yasemin Tanrıverdi ${ }^{1^{*}}$}

First received: 29.12 .2019

Accepted: 29.01 .2020

\section{Citation:}

IBAD Journal of Social Sciences

Issue: 6

Pages: $390-408$

Year: 2020

Session: Winter

This article was checked by iThenticate. Similarity Index 4\%

${ }^{1}$ Mimar Sinan University, Turkey, yasem.t5@gmail.com

ORCID ID 0000-0002-6869-4454

\footnotetext{
* Corresponding Author
}

\begin{abstract}
Water, with its vital importance, is among the most basic elements in human history. Soil, the basic material of ceramics, comes to life through water. Covering a wide area on the world, water is an important imagery in the field of art. It represents purification in almost all religions. Water, which contains contrasts in itself, is also the imagery of life and death for societies. Water imagery, which has an important place in human life, has been the starting point of many artists' works. The way the artists deal with the water imagery in their works differs from each other. Relative to the imagery of water that is established in the memory, it appears in the art artifacts in various ways. Sometimes, it appears with the trace left by water, sometimes with the shape that it represents, and sometimes, it appears as the form that it contains In this study, the imagery of "water" on cultures is investigated and also the ways that artists use this imagery are examined. In the relationship established with memory, the imagery in question has been reflected in the reflections of ceramic artists works.
\end{abstract}

Keywords: Water, Image, Ceramic Art, Memory, Culture. 


\section{GÍRISS}

"Eğer su kaynağı senin kendi ruhundan fişkırmazsa, susuzluğunu dindiremezsin."

\section{Goethe (Waterwall, 2015: Ekim)}

İnsanlığın doğuşundan bu yana su, vazgeçilemez bir yaşam kaynağı olmuştur. Yokluğunda yaşamın sürdürülmesinin imkânsız olduğu bu doğal kaynak, insan hayatında olduğu gibi doğa için de önemlidir. Suyun, iki Hidrojen ve bir Oksijen atomundan oluşan, tatsız ve kokusuz bir molekül olduğu bilinmektedir. Kimyasal formülü H2O'dur, doğada ise su katı, sıv1 ve gaz hâllerinde görülmektedir (http 1). İnsan, içinde bulunduğu doğa ile sürekli etkileşim halindedir. Birçok sanatç1 eserlerinde doğayı ele almıştır. Yaşam için bu denli önemli yere sahip olan su, sanatçılar tarafından farklı imgelerle eserlere yansıtılmıştır. Sanatsal anlatımın bir ifadesi olan mitolojik imgeler, sanat yapıtlarında sıkça karşımıza çıkmaktadırlar. Su, geçmişten bu yana birçok kültürün imgesi olarak görülmektedir. Su, kendi içerisinde sevinci ve hüznü barındıran alegorik anlatımı içeren bir imgedir.

Tarihi kalıntılar incelendiğinde, insanın suyla olan ilişkisi hakkında bilgi alınmaktadır. Eski medeniyetlerde, yaşama biçimleri incelendiğinde, şehirler arasında kurulan su kemerleri, kanallar, suyu toplamak için yapılmış havuzlar, sarnıçlar, kuyular, bentler ve ilerleyen zamanlarda barajların inşa edildiği görülmektedir. Yaşam alanları içinde suyu kullanmak için, şadırvanlar, sebiller, çeşmeler, kaplıcalar, 1lıcalar, hamamlar yapılmıştır (Avşar, 2016, s. 628-658). Günlük yaşantıda ise suyu taşımak veya muhafaza etmek için çamurdan üretilmiş seramik testiler, amforalar, ibrikler, sürahiler içinde bulunduğun topluma göre farkl1lık göstererek üretildiği görülmektedir.

Salgın hastalıklara rastlanıldığı temizlik sorununun olduğu coğrafyalarda insanların hayatlarını kaybettiği bilinmektedir. Bu sebeple temizlik her dönemde önemini sürdürmeye devam etmiştir. Yapılan araştırmalardan çıkan sonuçlara göre eski çağlarda insanoğlunun çoğunlukla su kenarlarında yerleşim yeri kurdukları, temizleme ve yıkanma ihtiyaçlarını akarsu, dere ve benzeri su kaynaklarında gerçekleştirdikleri bilinmektedir (Gökbel, 2019, s.57-68). Yine temizlenme ihtiyacından yola çıkarak hamamlar inşa edilmiş ve günümüze kadar varlığını sürdürmüşlerdir.

İmgeyi Ahmet Cevizci, Felsefe Terimleri Sözlügünde söyle açılar: Dış dünyamızdaki nesnelerin bilincimizde resmi, tasarımı veya taklidi; gerçek ya da gerçek dışı bir şey veya olgunun belleğimizde oluşan sureti, tasarımıdır; zihnimizde resimsel özelliği olan tasarım; duyusal bir niteliği, veya dış dünyada bulunan bir noktanın kopyasını, duyuların uyarıcılarının olmadığında meydana gelmesi sürecinin bir sonucu olarak zihinde var olan nesne (Cevizci, 2000, s.179). İnsan, imgeler sayesinde düşünür ve yaşamına şekil verir.

Sanatçılar, eserlerinde zihinlerinde var olan imgeleri yeniden kurgulayarak sanatsal bir zemin içerisinde yapıtlarını oluştururlar. Üretilen sanat yapıtı artık yeni bir imgeyi temsil etmektedir. Sanat yapıtlarında imgeyi anlamak için, eserin içeriğini iyi kavramak gerekmektedir. Kişiler kültürlerle olan ilişkilerini imgeler üzerinden kurarlar. Dolayısıyla eserin içeriğini kavramak eserin anlaşılmasına yardımcı olur. Kişi zihni, bedeni ve bütünlüğü hakkında daha çok bilgi ve fikir sahibi oldukça, içinde bulunduğu kültürün ve imgelerin rolü de farklılaşmıştır. İmgeler, artık, kişilerin eylemlerinin temsilleri veya tasvirleri değildir. Kişileri, birbiriyle ve teknolojiyle buluşturan bütün etkinlikler, dolayımlayıcı, biçim, arayüz olarak, kişilerin yaratım sürecini görünür kılan, durum rolü oynamalarının dışında, bilgi ve bilginin referanslarının merkezi durumundadır (Burnett, 2012, s.19). Sartre ise, varoluşu imge olarak ele geçirilebilmekte zorlandığımız bir varlık kipi olarak değerlendirir. Sartre, imgeyi anlamak için zihni yoklamak gerektiğini düşünür. Ona göre, imge olarak kâğıt yaprăğ ile gerçekte olan kâğıt yaprağı, kendi içlerinde farklı iki varoluş düzlemindedir. Sartre'a göre: İmge, nesne ise, imgenin de bir nesne gibi var olduğu sonucuna varılabilir (Sartre, 2017, s.7). René Magritte'in "Bu Bir Pipo Değildir" adlı eseri bu kavram ile yapılmış belki de en etkili yapıttır. Eser "Görüntülerin İhaneti" olarak da adlandırılmaktadır. Magritte'ye göre: "Bir nesnenin adı kimi zaman, bir imgenin yerini alabilir. Ya da bir sözcük de aynı şekilde gerçekte, bir nesnenin yerine geçebilir. Bir önermede yer alan sözcügün yerini yine bir imge de alabilir" (Foucault, 2001, s.38). Magritte'in anlatmak istediği; öğrenilmiş bir şey olan pipodan bahsedildiği zaman, pipo imgesi zihinlerde canlanır. Fakat bir portakalı pipo diye öğrenmiş olsaydık, pipo denildiğinde aklımıza ilk portakalın imgesi gelirdi. Bir sanat eserini incelerken eserin içeriği bu 
açıdan önem taşımaktadır. Görüntünün bizdeki imgesiyle eserin içeriği farklı anlamlar taşıyabilir. Sosyolog olan Connerton ise imgenin toplumlar üzerindeki etkisini, "yaşantımız esnasındaki deneyimlerimizin, geniş ölçüde geçmiş, yaşanmışlıklar üzerinden kurulduğunu ve geçmişten gelen imgelerimizin ise kurulmuş olan toplumsal düzeni yasallaştırdığını söylemektedir" (Connerton, 2011, s.12). Ona göre, kültürlerin devamlılığı açısından imgelerin tekrarı kalıcıllğg sağlar. Eliade'ye göre imgeler, taklit etmekte, olanları sonsuzca tekrar etmektedir. Dünyayı bütünsel olarak görmek için

imgeleme sahip olmak gerekmektedir. Nedeni ise, kavramsallaşmayan her şey, imgelerin sorumluluğundadır ve onun görevi durumundadır (Eliade, 2017, s.29).

Mitler; kuşaktan kuşağa yayılan, toplumun düş gücü ile zamanla genişleyip biçim değiştiren, toplumun ortak inançlarını ve düşüncelerini imgesel, benzetimli bir anlatım biçimi ile dile getiren, toplumsal öykülerdir. Su imgesi ise yıllar boyunca mitler aracılı̆̆ ile günümüze kadar gelerek kutsal kitaplar yoluyla toplumlara aktarılmıştır. Kutsal bir kitap olan Tevrat, yaratılış tasviriyle başlar. Tasvir şöyledir: İlk başta her yerin karanlık içinde olduğu, Tanrı'nın kutsal ruhunun suyun yüzeyinde yürüdüğü, Tanrı'nın ilk önce 1şığı, gündüzü ve sonra geceyi yarattığı söylenir. Ertesi gün ise Tanrı'nın suların üzerinde bir kubbe istediği ve yaratılan bu kubbeye de 'gök' adının verildiği anlatılır. Üçüncü güne gelindiğinde Tanrı'nın suları ayırarak kuru toprağı yarattığı ve adına da 'yer' denildiği anlatılır. Yine Tanrı'nın, denizi de suların oluşturduğu birikintiyle yaptığı şeklinde tasvir edilmiştir (Gezgin, 2018, s.83). Bir başka kutsal kitap olan İncil'de ise verimli yağmurların kutsal kenti Kudüs'ten doğan bulutlarla dünyaya dağıldığına inanılır. Kudüs bol sularıyla betimlenir. Yeryüzünün bereketini sağlayan, toprağı sulayan kaynak Kudüs'tedir. İncil'de yer alan vahiy bölümünde Yuhanna göksel melekler aracılığıyla gördüğ̈̈ Kudüs şehrini anlatır. Hıristiyanlık inancında tatlı ve tuzlu sulara farklı atıflarda bulunulur; tuzlu su çoğunlukla canavarların geldiği, yılanın çıktığı yerlerdir. Dolayısıyla şeytanı barındıran kötü özelliğe sahiptir. Fakat tatlı sular özellikle vaftiz yoluyla ruhun, yeniden doğuşunu sağlar ve bedene şifa verir (Gezgin, 2018, s.85). Son semavi din olan İslam dininin kutsal kitabı Kuran-1 Kerim'de su yine özel bir konuma sahiptir. İslam inancında Hz. Muhammed yağmur ile özdeşleştirilmiştir. Peygamber için kasidelerde su "rahmet yağmuru" olarak anlatılmaktadır. Dört büyük melekten birisi olan Mikail doğa olaylarını kontrol etmekle görevli melektir. Yağmurun yağmasına Mikail aracılık eder (Gezgin, 2018, s.88). Su bütün kaynaklarda temizliğin, yaşamın yani doğumun ve ölümün simgesidir.

Gaston Bachelard "Su ve Düşler" kitabında maddenin doğrudan imgelemleri olduğundan bahseder. Ona göre maddenin imgeleri içsel ve tözsel olarak, formlardan uzaklaşıp, gelip geçici formlardan, anlamsız imgelerden, yüzeyin geleceğinden ayrıştırarak düşlemek gerekmektedir. Bachelard'a göre tözsel olarak su imgesi, ateşe göre daha dişil, daha tel biçimli, insanoğlunun en gizli, en yalın, en sadeleştirici güçlerini sembolize etmektedir (Bachelard, 2006, s.12). Ancak su, Bachelard'a göre şiirlerin içerisinde süsleme mahiyetinde kullanılırken tözden uzaklaşılmıştır.

\section{TARIHTE SUYUN FONKSIYONEL VE SANATSAL SERAMIK OBJELERLE BAĞLANTISI}

Yaşamın önemli bir parçası olduğu için suyu içinde taşıyan seramik kaplar da önemli olmuş, belleğin taşınmasına yardımcı olmuşlardır. Farklı alanlarda kullanılan su ve türevleri incelediğinde dönemin kültürü ve yaşam biçimi ile ilgili de bilgiye ulaşılabilmektedir. Bellek aktarımında önemli bir yere sahip olan bu seramik kaplar sadece kültürel aktarımı sağlamakla kalmayıp bazı seramik sanatçılarının da sanat üretiminde yol gösterici olmuştur. Tarihte suyun taşındığı seramik formlar incelediğinde; çeyiz olarak günümüze gelen kaplar ve zemzem şişesi olarak üretilmiş kapların bölgenin kendine ait özelliklerini taşıdıkları görülmektedir. 


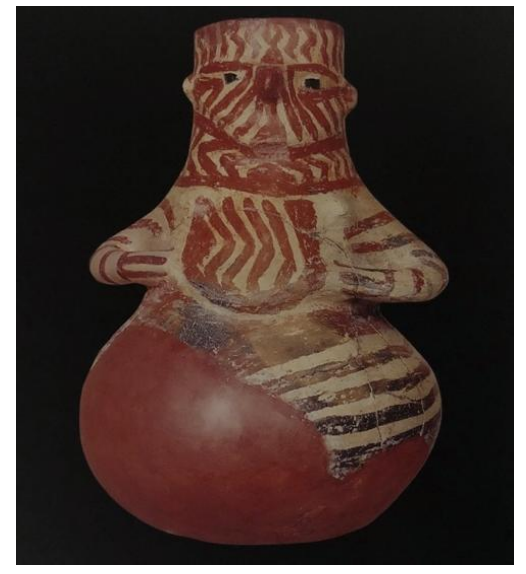

Görsel 1. Kadın Formlu Çömlek, Terakota pişmiş kırmızı toprak, Hacılar, Kalkolitik Çăg, M.Ö. 6. binyllın son çeyreği, y: 28,7 cm., ç: 20,4 cm, İstanbul Sadberk Hanım Müzesi

Paleolitik (Eski Taş Devri) Geç Neolitik ve Erken Karakolitik dönemlerde (M.Ö. 5400-4750) insanlar; havaların ısınmasıyla su kenarında yaşamaya başlamışlardır. İlk köyleri bu dönemde kurmuşlardır. Tarım hayatı ile birlikte üretim faaliyetlerine başlamışlardır. Buğday, arpa, bezelye gibi bitki ekimine başlamış, taş araç ve gereçlerin yanında yiyeceklerini korumak düşüncesiyle topraktan da araç ve gereçler yapmışlardır. At, koyun ve sığır gibi hayvanları evcilleştirmişler, bitki liflerinden giysiler yapmışlardır. Tüketici durumdan üretici durumuna geçmişlerdir. Tekerleği icat etmişlerdir. Böylece ulaşım daha kolay hale gelmiştir. Taş temelli ve düz çatılı kerpiç evlerin inşasını içeren sosyal ve yerleşik bir yaşama geçiş süreci muhtemelen birkaç milyon yıl sürmüştür. Bu açıdan Neolitik dönem özellikle büyük öneme sahiptir (Sadberk Hanım Museum, 1996, s.11). Anadolu'da yapılan arkeolojik araştırmalar ve kazılarda farklı dönemlerde farklı bölgelere ait seramik su kapları görülmektedir. Seramik su kapları vasıtasıyla döneme ait bilginin yanı sıra her dönemde suya verilen önemin bilincine tekrar tekrar varılmaktadır. Görsel 1'de yer alan kadın formlu çömlek Hacılar'ın Son Neolitik ve Erken Kalkolitik Çağlara aittir. Hacılar'da bulunan bahsi geçen çömlek, çömlekçi çarkının henüz icat edilmediği bir dönemi temsil etmektedir. Bölgede yapılan kazılarda çamurdan el ile şekillendirilmiş, kırmızı, kahverengi ve devetüyü renklerinde boyanmış, çömleklere rastlanmıştır. Seramikler, geometrik motiflerle dekore edilmiştir ve çok çeşitli formlara rastlanmaktadır. Dönemin sanatı kadın biçimli figürler ile temsil edilmektedir. Arkeoloji literatüründe "steatopygic" olarak adlandırılan bu nesnelerin, Anadolu'da hemen hemen her kültürde tekrar tekrar ortaya çıkan "Ana Tanrıça" figürünün ilk örnekleri olduğu düşünülmektedir (Sadberk Hanım Museum, 1996, s.11). İnsanoğlu binlerce yıldır üreme sürecini anlamaya çalışmıştır. Karakolitik dönemde "hieros gamos" adını verdikleri, Tanrı ve Tanrıçanın kutsal birleşmesi şeklinde sembolize edilen ilahi bir yaratım olduğuna inanılmaktaydı (http 2). Bir ritüel kab1 olarak üretilmiş söz konusu kadın formlu çömlekte, libasyon esnasında tanrılara adanan kutsal sıvıların sunulması işlevi için kullanılmıştır. Kabın üst kısmı bir yüzü, alt bölümü ise, geniş kalçaları olan hamile bir kadın bedenini temsil etmektedir.

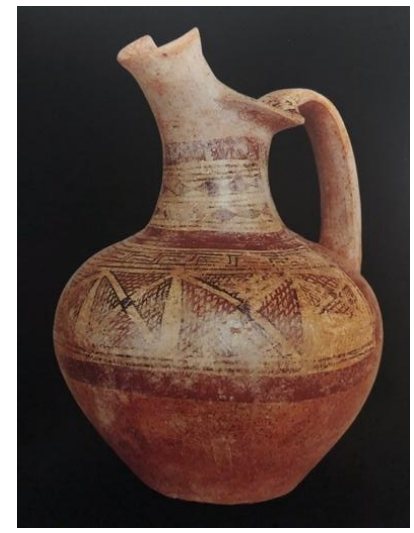

Görsel 2. Kesik Gagalı Sürahi, Pişmiş Toprak, M.Ö. 7. yüzyıl, y: 31 cm, İstanbul Sadberk Hanım Müzesi 
Yine Anadolu'da yapılan arkeolojik kazılarda el yapımı, yüksek derecede pişirilmiş, kırmızı ve kahverengi pişme rengine sahip çamurdan yapılmış perdahlı kapların ortaya çıktığı görülmektedir. Demir Çağı (Karanlık Çağ) olarak geçen Çağ (M.Ö. 1200-750) M.Ö. 2. binyılın sonundan M.Ö. 1200-1050 yıllarına kadar olan dönem, sadece Doğu Akdeniz'de değil, Anadolu ve Balkanlar'da da büyük hareketlerle sonuçlandığı bilinmektedir. III. Ramses Medinet Nabu'daki tapınağındaki yazıtlar, kuzey kabilelerin sadece Anadolu'ya ve Kıbrıs'a nüfuz etmekle kalmayıp, Mısır'ın güneyine kadar ulaştığını göstermektedir (Sadberk Hanım Museum, 1996, s.25). M.Ö. 13. yüzyılda Miken Krallığı'nın çöküşünün neden olduğu Doğu Akdeniz'de yaşanan bozukluklar, Hitit toprakları altında yüzyıllarca yaşamış olan sayısız yerli Anadolu halkına huzursuzluk yaşatmıştır. Güneydoğu Avrupa'dan işgalci Hatusas'ın Hitit başkentini yıkıp, sonunda Asur sınırına ulaşan işgalci kabileleri tarafindan yok edilmiştir. Bu kaosun hemen sonucu, Anadolu'nun yaklaşık 450 yıl süren yoksullaşmasına neden olmuştur. Özellikle Orta Anadolu'da, bugüne kadar sayısız kazıların M.Ö. 1200 ve 750 yılları arasında önemli kültürel değere sahip, çok az kalıntının ortaya çıktığı görülmektedir (Sadberk Hanım Museum, 1996, s.25). Yaşamın vazgeçilmez bir parçası olan suya ait seramik kalıntılar günümüze kadar gelebilmiştir.

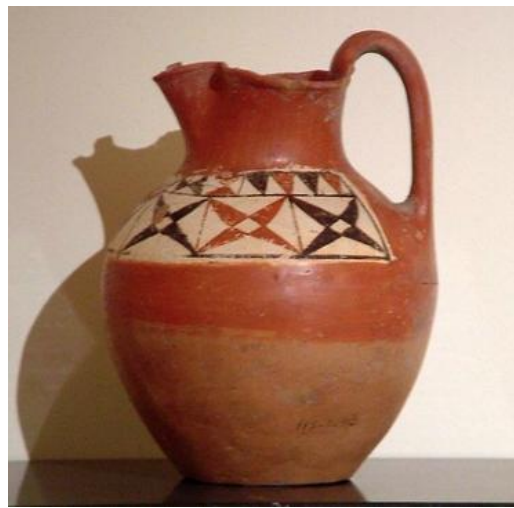

Görsel 3. Yonca ă̆ızl, boya bezemeli testi, Frig Uygarlı̆̆l, Pişmiş Toprak, M.Ö. 8.yüzyll, y: 20.9cm,

\section{Anadolu Medeniyetleri Müzesi}

Frig, coğrafi ve siyasi konumu nedeni ile kaosun yaşandığı Demir Çağ döneminde varlığını sürdürmüş olan bir uygarlık olduğu bilinmektedir. Yonca ağızlı seramik sürahi, Frig kültürünün temsili olarak M.Ö. 950- 800 arasına tarihleri arasındaki döneme aittir. Erken Frig Dönemi’nde gri ve siyah renkli kaplar yaygın bir şekilde görülmektedir. Çoğunlukla çömlekçi çarkında yapılmış olan seramiğin kaba ve kalın cidarlı olduğu görülmektedir. Yonca ağızlı testiler, düz ve ayaklı tabaklar, maşrapalar bu dönemin en yaygin formları arasindadır (Erdan, 2015, s.109).

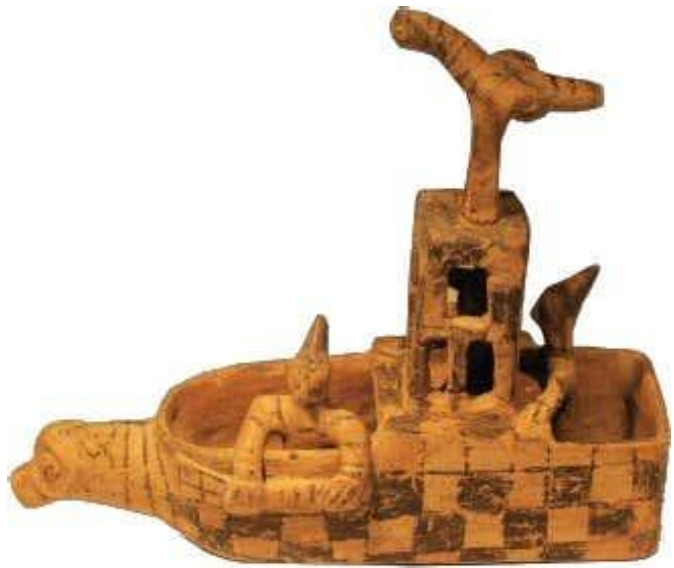

Görsel 4: Sandal Biçimli Törensel Kap, Kültepe Kalıntısı, M.Ö. 3 binyıl, (ö.y.), Anadolu Medeniyetleri Müzesi 
Kültepe, tarihsel olarak farklı bir öneme sahip olmuştur. Asurluların burayı bir pazar şehri olarak kullandığı bilinmektedir (Ateş, 2014, s.4). Asurlular, Anadolu'da Ticaret kolonilerine ev sahipliği yapmış kendilerine ait kültürel öğelerin başka kültürlerle buluşmasına vesile olmuşlardır. Söz konusu dönemde üretilmiş olan seramiklerden halkın refah seviyesinin yüksek olduğu, bu döneme kadar üretilen seramik kapların sadece kullanıma yönelik olduğu, Asurlularla birlikte sanatsal seramikler üretildiği görülmektedir. Kültepe'de bulunan Kült kabının özelliği ise tapınak ve içerisinde yer alan tanrıça heykelciklerinin bulunmasıdır. Eski Mezopotamya'da ulaşım, ticaret ve ritüeller esnasında kullanılan tanrı sandalları Sümer Edebiyatı'nda da önemli bir yere sahip olmuştur. Törensel Kap, bir şenlik esnasında bir nehir boyunca kült heykellerinin gezdirildiği dini bir ritüeli temsil etmektedir (Ateş, 2014, s.6). Denizler yüzyıllar boyunca insanların ulaşım yolu olmuştur. Eski çağlarda deniz ulaşımının yoğun yapıldığ 1 dönemlerde, denizin kültürler arası etkileşime aracılık ettiği bilinmektedir. Batık gemilerden çıkan seramik buluntular, bu etkileşimin örnekleri olmaktadır.

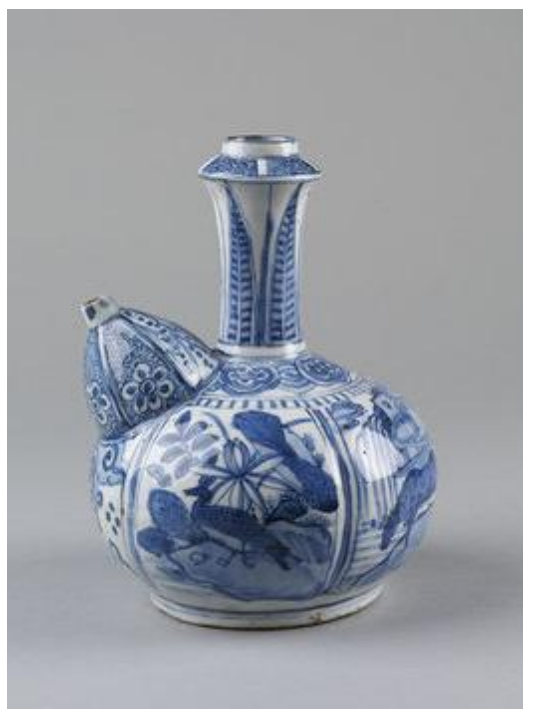

Görsel 5. Kendi Jingdezhen, Çin, Ming hanedanı, 1590-1615, Porselen, y: 19,7 cm, ç: $15 \mathrm{~cm}$, V\&A Müzesi

Çin'in Ming hanedanlığı döneminde, 1573-1620 yılları arasında üretilen Kendi su kapları, mavi sıraltı ile dekorlanmış porselen kaplardır. Uzun boyun kısmı ve kubbe şeklinde bir emziğe sahip küresel formda porselen kaplardır. Görsel 5'te yer alan kabın alt bölümünde, bir kuş, at, leylek ve böcek dekorları mevcuttur. Aynı işlev için kullanılan su kapları üretildiği bölgenin kültürüne göre form ve dekor bakımından farkl11ıklar göstermektedir.

Bazı seramik formlar üretildikten sonra sadece bulunduğu bölgede varolmuş, dışarı açılamamıştır. Bazıları ise yine belli bir bölgede üretilip yayılmıştır. Popülerliği fazla olan formlar, yüzlerce yıl devamlılığını sürdürmüş, geniş bölgelere yayılmıştır. Kendi formlu su kapları da dikkat çekici formlardan biri olmuştur. Güneydoğu Asya'da yaygın olarak kendi olarak bilinen bu kaplar, kundika'dan gelen Sanskritçe adı Kunda'dan türetilmiş Malayca bir kelimedir. Bazı akademisyenler, kendi kelimesinin kundika kelimesinden evrimleştiğini varsaymışlardır. Eşyaların işlevi yazıtlarda veya Recańtawswan olarak Budist'lerde ritüellerde "serbestleşme" anlamına gelmektedir. Kendi, sembolik olarak su dökmek için sadece Budist kutsama töreninde kullanılan su kabını ifade etmektedir (Tutor, 2011, s.4). 


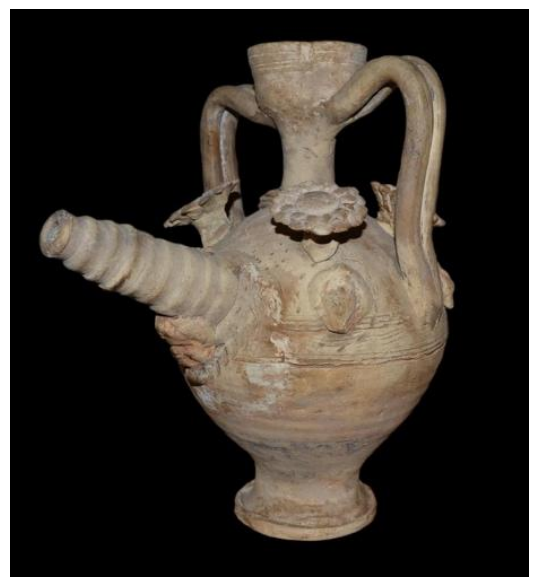

Görsel 6. Gargoulette sürahi, Fransa bölgesi, 17. Yüzyll, Rönesans tarzl, g: 26,8 cm, ç: 16,4 cm, y: 28,7 $\mathrm{Cm}$

Fransa'nın güney bölgesinde üretilmiş olan Gargoulette sürahileri 17. Yüzyıl'a aittir. Gargoulette sürahileri uzun boyunlu olup, geniş bir gövdeye sahiplerdir. Büyük bir emzik kısmı vardır. Genellikle arabesk süslemelere sahip formlardır. Görsel 6'da yer alan her tarafta süslenmiş, nadir bulunan gargoulette sürahisi, gövdesinde melek kafaları, dört çiçek ve bir süzgeç olmak üzere iki dolgu boynu, iki büyük kulp ve büyük bir emziğe sahiptir.

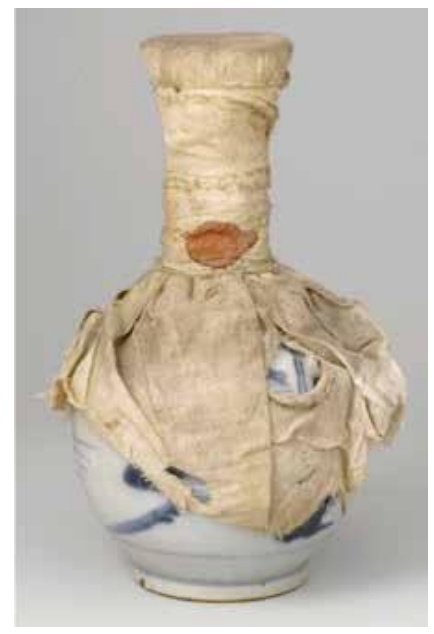

(7)

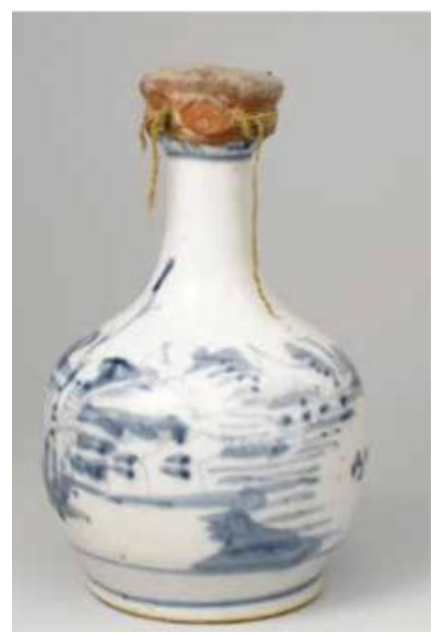

(8)

Görsel 7. Terakota pişmiş toprak Şişe, Çin, 19. yüzyıl Porselen, TSM. Çin Porselenleri Koleksiyonu, y: $21.5 \mathrm{~cm}$

Görsel 8. Terakota pişmiş toprak Şişe, Çin, 19. yüzyıl Porselen, TSM. Çin Porselenleri Koleksiyonu, y: $21.5 \mathrm{~cm}$

Su kapları kimi zaman yaşama kaynağı olan suyu taşımak için kullanılırken, kimi zaman da dini ritüellerde kullanılmak için üretilmiştir. Görsel 7'de yer alan şişe ise zemzem suyu taşımak için üretilmiştir. İslam kültürünün beşiği olan Hicaz bölgesinde su kaynakları az olduğu için kuyular oldukça önemli olmuştur. Tüm bu kuyular içerisinde hiçbiri Müslümanlarca kutsal kabul edilen zemzem kuyusu kadar önemli olmamıştır. (Kü̧̈ükaşcı, 2017/2, s.75). Söz konusu kaplar zemzem suyu şişeleridir. Zemzem Suyu Mekke'den getirilen kutsal bir su olması nedeni ile taşınması için özel sürahiler üretilmiştir. Porselen kapların tercih edilme sebebi ise zor ve uzun yollar boyunca taşınan bu suyun hijyenik açıdan korunmasını sağlamaktadır. Zemzem suyu şifa niyetine kullanılan kutsal bir sudur. Bu suyu uzak mesafelere taşımak için özel kâseler üretilirdi. Kâsedeki suyun, su ile doldurulmuş olan sürahilere sızmasına izin verilir, daha sonra sürahiler kırmızı balmumu ile kapatılır ve önemli kişilere verilirdi. Bu kaplar, hasta insanları tedavi etmek amacıyla hızlı bir şekilde kırılabilmek ve hijyeni sağlamak için genelde porselenden üretilmiştir. Bu uygulama, Sultan II. Mahmut tarafından 
durdurulmuş, çünkü bazı bitkisel dükkanlar, "Hırka-i Saadet Suyu" adı altında sahte su satmaya başlamıştır (Aydın, 2004, s. 763).

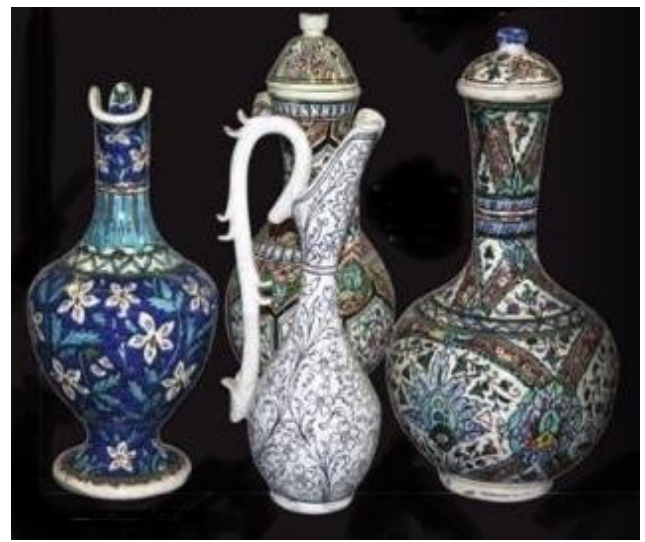

Görsel 9. Kütahya işi seramik sürahi gurubu 20.yüzyıl, Adell Armatür Kolleksiyonu

Geçmişteki testilerden çağımızda farklı formlara dönüşen 20. yüzyıla ait söz konusu farklı formdaki su şişeleri, gelin çeyizlerinde, gelin ve damat için özel olarak hazırlanmış olarak görülmektedir. Aynı zamanda bölgenin ekonomik olarak kalkınmasında da önemli rol oynamıştır.

\section{SANATSAL İMGE OLARAK SU}

Su taşıdığı önemden ötürü sanatçıların sıklıkla kullandığı vazgeçilmez bir tema olmuştur. Suyun nesilden nesile aktarımında kullanılan imgelerin, sanatçıların eserlerinde yansıması farklılıklar göstermektedir.

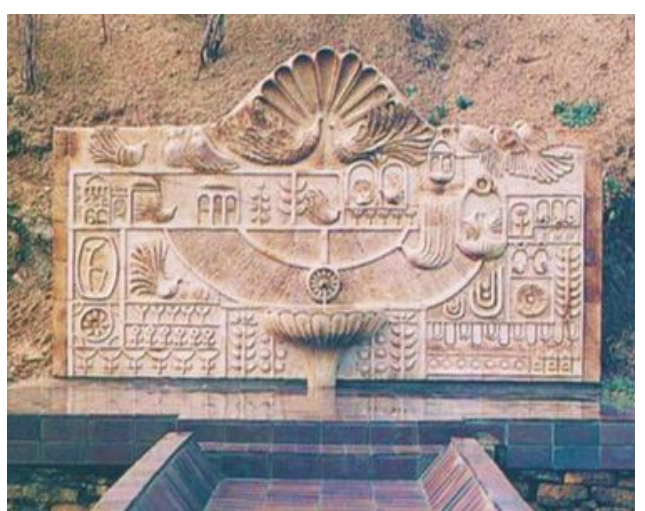

Görsel 10. Hamiye Çolakoğlu, "Derman Çeşmesi”, Hacettepe Üniversitesi Beytepe Kampüsü girişi, Ankara, 1986

Sanatçı Hamiye Çolakoğlu'nun 1986'da kamusal alan olan Hacettepe Üniversitesi Beytepe Kampüsü girişine yapmış olduğu "Derman Çeşmesi" adlı seramik eseri, Anadolu'daki kültürü içerisinde yapılmış olan ç̧eşmeleri anımsatmaktadır. Eserin yüzeyinde taşıdığı kabartma motifleri aynı zamanda kültürel izleri içerisinde barındırmaktadır. 


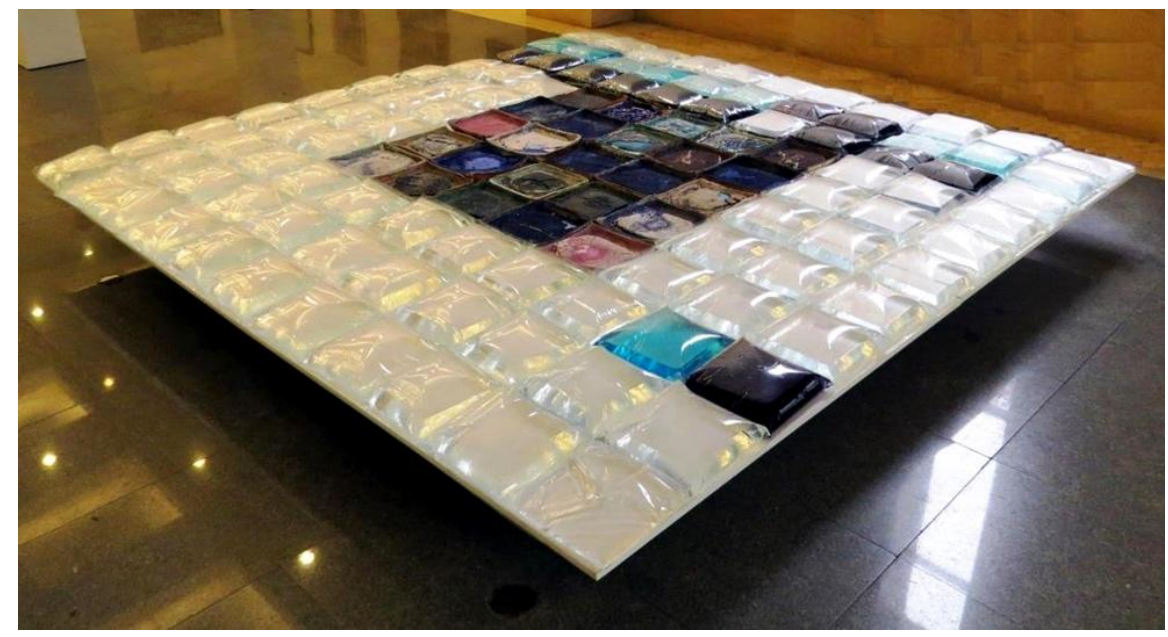

(11)

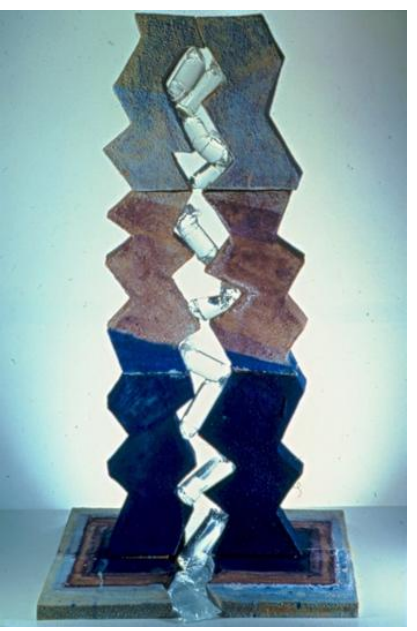

(12)

Görsel (11). Güngör Güner, “Toprak, Su Illişkisi ve Saydamlık”, 330x290 cm, 1993

Görsel (12). Güngör Güner, "Suyu Sergiliyorum”, y:225 cm.g:60 cm. d:25 cm., 1999

Seramik sanatçısı Güngör Güner "Suyu Sergiliyorum" adlı sergisinde yerleştirmesini şöyle ifade etmiştir; 1993 yılında yaşamı boyunca hiç tanık olmadığı bir kuraklık yaşanmıştır. Nerdeyse hiç yağmur yağmayan bir kış yaşanmıştır. İlkbahar mevsiminin gelip çattığı dönemde ağaçlar çok kurumuştur. Sonrasında yağan yağmurun hiç yere düşme şansı bile olmadığını gören Güner, yaşadığı bu kuraklıktan çok etkilenmiş, sonrasında susuzluktan yola çıkarak yapıtında toprak-su ilişkisini ele aldığı bir sergi hazırlamıştır (Güner, Röportaj, 2019).

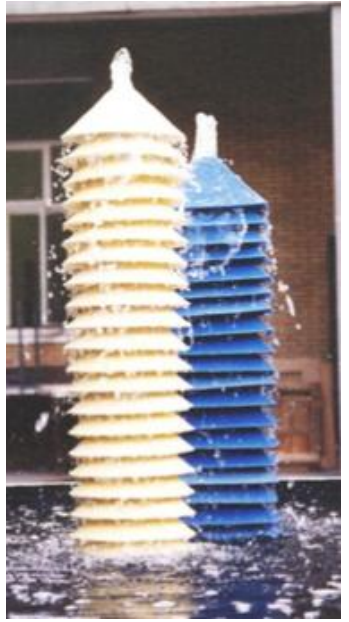

(13)

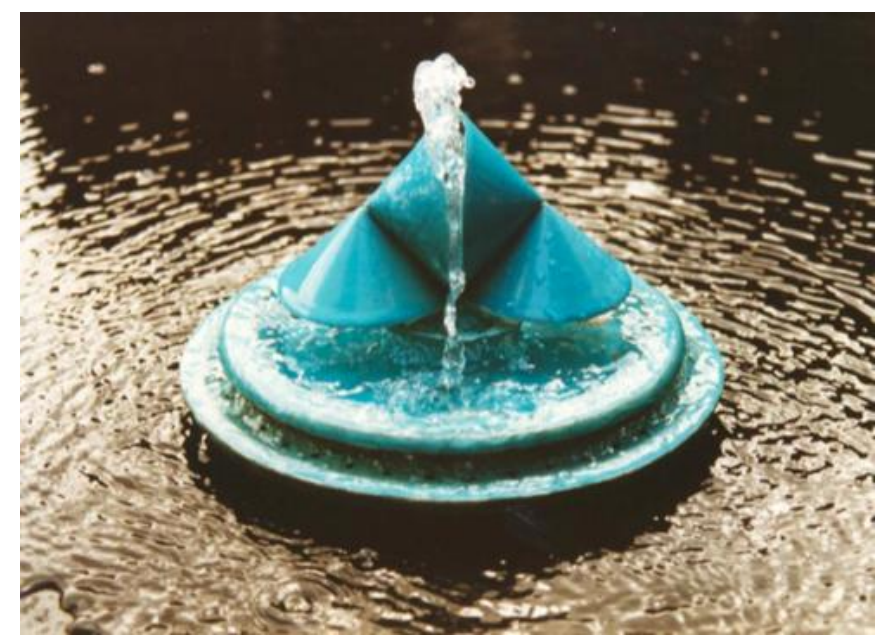

(14)

Görsel (13), (14). Cengiz Ertekin, seramik havuz, (ö.y), (t.y.)

Cengiz Ertekin'de eserlerinde suyu kullanan sanatçılardan biri. Sanatçı kamusal alan içerisinde seramik havuzu üretmiştir. Eser modüler parçaların bir araya gelmesi ile üretilmiştir. Görsel 13’te kalıp alınarak elde edilmiş koni şeklinde üretilmiş seramik bir yapı görülmektedir. Görsel 14'te ise Ertekin tarafindan tasarlanmış bir seramik süs havuzu yer almaktadır (Gordon, 2013, s.41). 


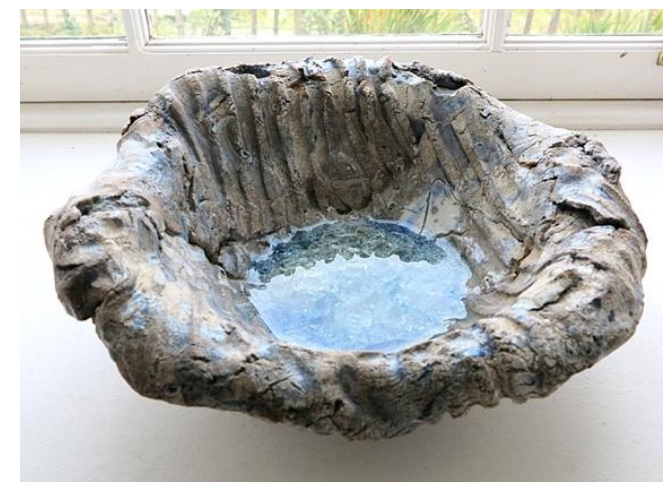

(15)

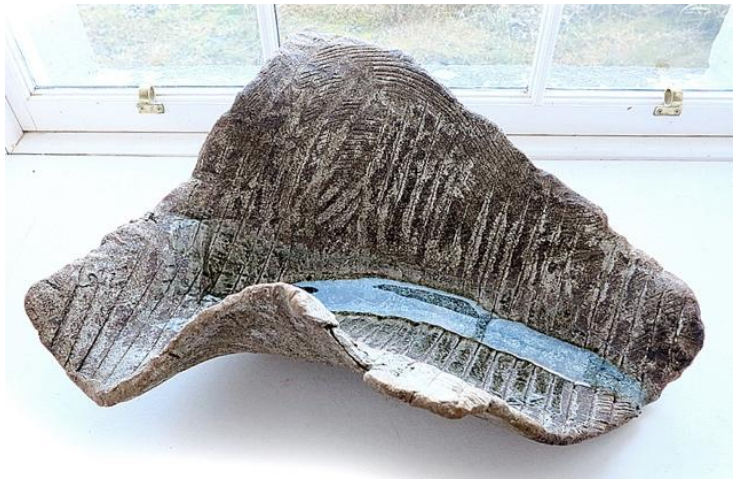

(16)

Görsel (15). Nicklai Globe, "Donmuş Deniz”, 40cm x 15cm, 2012

Görsel (16). Nicklai Globe, "Nehir teknesi", 60cm x 50cm x $24 \mathrm{~cm} 2012$

Nickolai Globe, kendini arkaik eserlerini yarattığı Harris Adası ile bütünleştirmektedir. Sanatçı yüksek pişirim sıcaklığına sahip çanak çömlek, porselen, fayans ve yerel mineraller ile çalışmaktadır. Sanatçının son çalışmaları, seramikleri, heykel ve işlevin birleştiği, kendince zanaat türevi işlerden oluşmaktadır. Eserleri yüksek derece pişirimi olan formları daha jeolojik hale getirmekte ve etkilendiği İskoçya'nın batı kıyısında bulunan Hebridler'in arazisinin derin bir yansımasını taşımaktadır. Cam ve ham mineralleri çalışmalarına dahil ederek kelimenin tam anlamıyla manzarayı temsil eden eserler üretmektedir (http:3). Sanatçı eserlerinde doğadan yola çıkmakta ve etkisinde kaldığı suyu eserlerine aktarmaktadır.

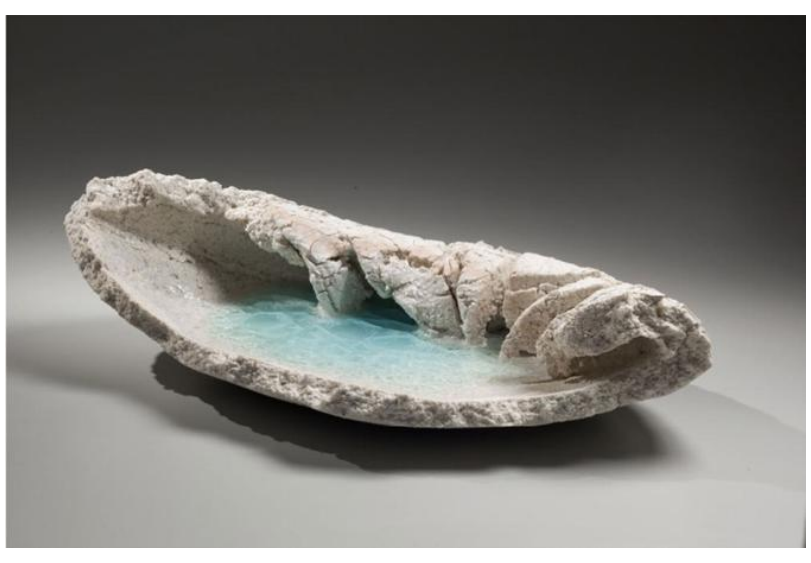

(17)

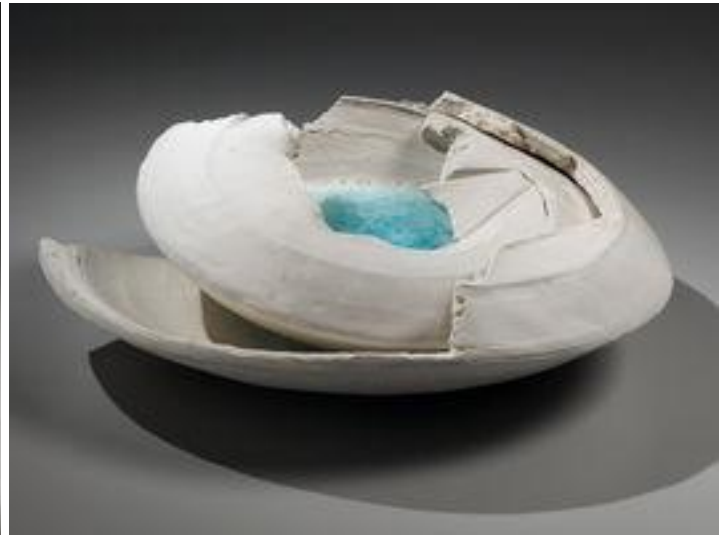

(18)

Görsel (17). Machiko Ogawa: Silika kumu ve Feldispatl porselen, porselen ve cam sir, 19.1x69.5x38.1 $\mathrm{cm}, 2014$

Görsel (18). Machiko Ogawa: Silika kumu ve Feldispatl porselen, porselen ve cam sir, $14 \times 47 \times 39.1 \mathrm{~cm}$, 2014

Ogawa Machiko'nun çalışmaları, seyahatlerinin birer yansıması olup kayalara ve minerallere olan ilgisini yansıtmaktadır. Ogawa Machiko uluslararası seyahatlerinde yıllarca kaya ve mineral toplayıcılığı yapmış, bu ilgisi onun yeteneğine ve yaratıcı serüvenine büyük katkı sağlamıştır. Sanatçının mineraloji serisinde, yeryüzünün derinliklerinden çıkmış parçalanmış kayaya benzeyen farklı keşifleri vardır. Söz konusu kayaya benzeyen heykellerin aksine "Kırılgan Heykel" serisi, arkeolojik bir kazıda ortaya çıkarılan ve elementler tarafından yıpranmış olan ilkel kırılmalar ortaya koymaktadır. Her iki seride de Ogawa, bir çöl zemini, kutup mağarası veya dağın altındaki en derin mağaralardan yola çıkarak çamur gövdesinde çarpık ve çatlak dokular kullanmaktadır (http:4). 


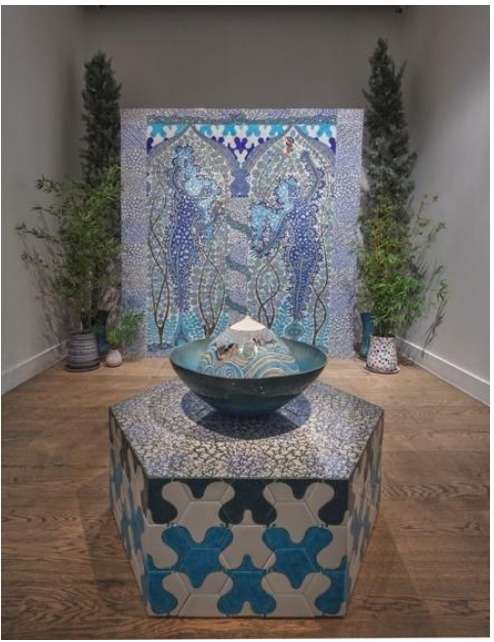

(19)

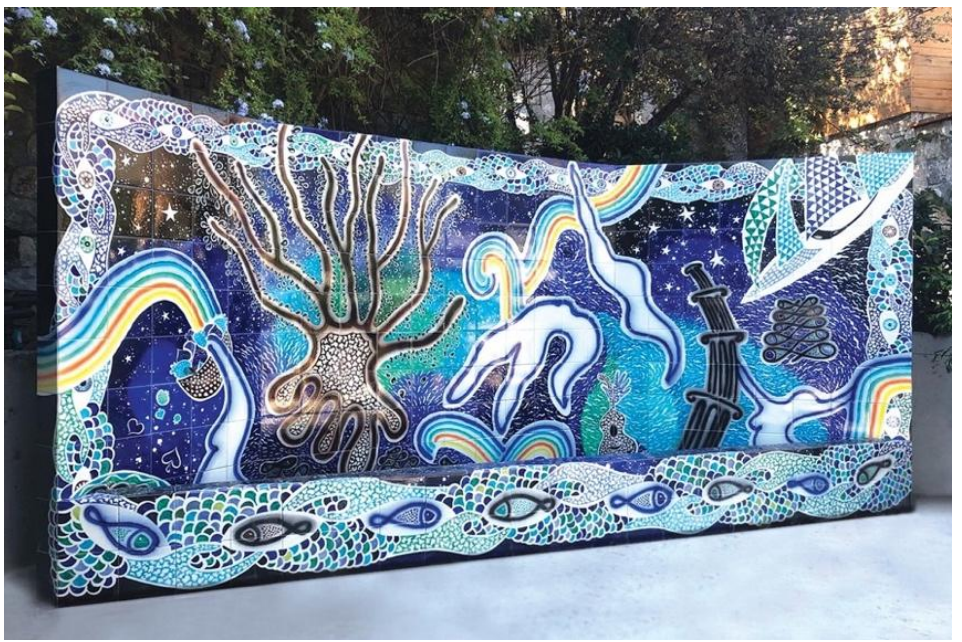

(20)

Görsel (19). Elif Uras, "Yaz / Klş ve İznik Gölü”, Galerist, Yerleştirme, 2016

Görsel (20). Elif Uras, "Ayla'nın yaz mevsimi” Maça Kızı Otel, Bodrum, 10 m., 2018

Elif Uras resimleri ve seramik eserlerinde, Türk seramik sanatının geleneksel, dekoratif desenlerini figüratif batı görüntüleriyle birleştirmektedir. Uras, Batı modernliği ile doğu sanatının ve kültürünün geleneksel özellikleri arasındaki değişken ilişkiyi eserlerine taşımaktadır. Sanatçı eserlerinde çoğunlukla kadın imgesinden yola çıkar. Uras'a göre su doğurganlığı ve bereketi temsil etmektedir. Dolayısıyla su, sanatçı için önemli bir ifade aracıdır. Sanatçı Doğu ile Batı arasında kurduğu ilişkiyi, Osmanlı İmparatorluğu zamanında bulunan hamam ve çeşme kültüründen esinlenerek kurar. Hamamlar Osmanlı'dan bu yana Türk kültüründe önemli bir yere sahiptir. Temizlik, arınma, bereket gibi birçok kavramı içerisinde barındırır. Geleneksel motiflerden yola çıkan sanatçı, su sembolünü sıklıkla kullanır. Sanatçının sergisinde kimi zaman, işlevsel bir seramik çeşme, galeri merkezinde yer alır. Su ve onun sürekli akışı, popüler bereket ve refah sembolleri, serginin çıkış noktasını pekiştirmektedir. Görsel 19'da yer alan "Çeşme" adlı eseri, sanatçının 2016 yılında açtığı sergisinde yer alan bir eser örneğidir. Sanatçı seramiğe olan ilgisini pekiştirmek adına sık sık İznik'e gidip oradaki atölyelerde çalışma yapmıştır. Orada edindiği deneyimleri kendi sanat anlayışıyla birleştirerek eserler üretmiştir. Görsel 20'de yer alan eseri ise yine İznik'te bulunan bir çini firmasıyla birlikte bir otel için yaptı̆̆ çalışmadır. Sanatçı bu eserinde deniz altı yaşamından esinlenmiştir.

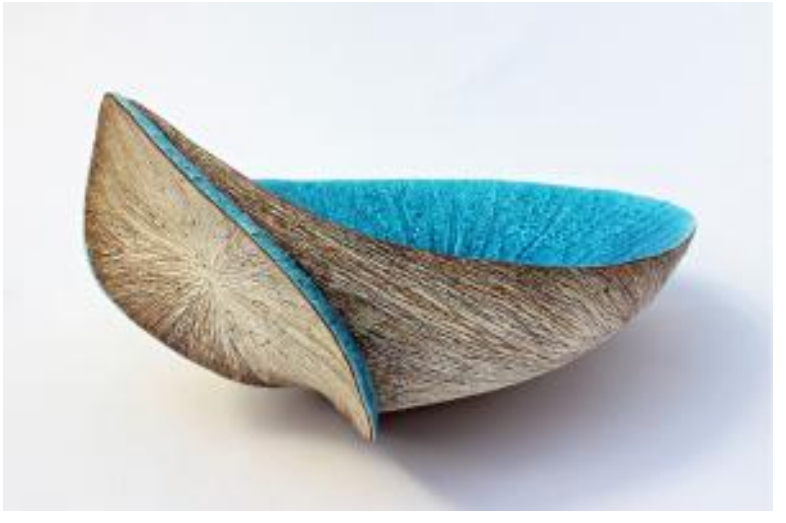

(21)

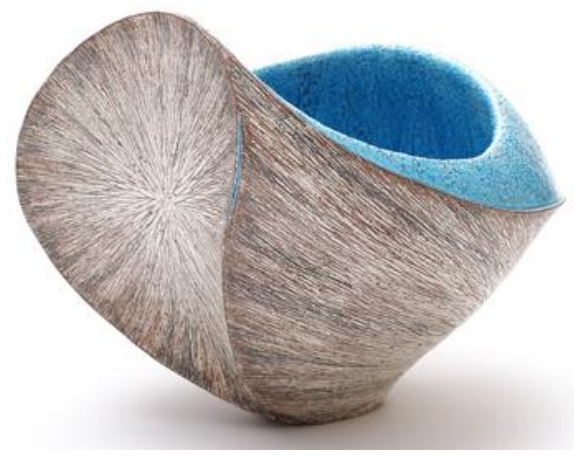

(22)

Görsel (21). Shinya Tanoue, "Deniz Kabuğu” 17, y.48x33x45.5 cm, 2017

Görsel (22). Shinya Tanoue, "Deniz Kabuğu” 17, y.28x 36 x 33 cm, 2017 
Deniz kabukları Shinya Tanoue'un eserlerinde değişmez bir tema olmuştur ve yaşadığı çevreyle ilişkili olduğu için sıklıkla ilgili konuyu ele almıştır. Sanatçının ürettiği parçaların her biri oldukça basit, ancak kendi içlerinde etkili bir kıvrıma sahip, çizgiler ve eğriler gibi detaylar içermektedir. Sanatçı eserlerinde farklı teknikler kullanmıştır. Eseri bir bobin yardımı ile oluşturduktan sonra, yüzeye kaygan bir çukur uygulamıştır. Sonrasında yüzeyi iğneler yardımı ile oluklu hale getirmiştir. Eserlerinin üretim süreci kullandığı teknikler açısından oldukça meşakkatli olup uzun bir sürece yayılmaktadır. Tanoue'un eserleri, seramik üretim tekniklerine olan tutkusundan ve çamur özelliklerini geliştirme ve maksimize etme arzusundan doğmuştur. Eserlerinde ilham kaynağı deniz kabuğu kavramıdır. Sanatçı, kabuk formuyla, bir taraftan kişiyi yumuşak bir şekilde sarmasını ve korumasını, diğer taraftan bunu yapabilecek gücü olan sertliğini vurgulamıştır. Ayrıca, toprak kaplar rahim kavramına yakın koruyucu bir kabuk oluşturduğundan doğum ve yaratma kavramına da gönderme yapmaktadır. Sanatçı sırlarında genellikle, Japon kültüründe sembolik olarak yaşam kaynağı olan suyu hatırlatan mavi rengi kullanmaktadır (http:5).

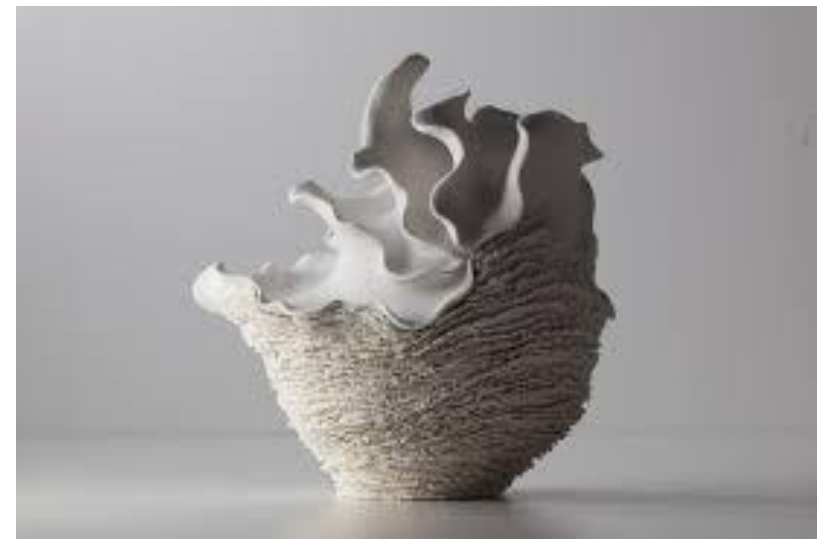

(23)

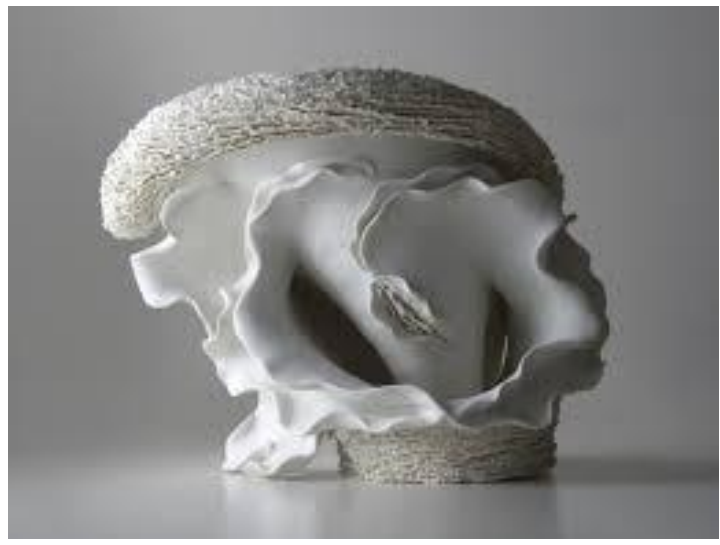

(24)

Görsel (23), (24). Noriko Kuresu, “Denizin Belleği”, (ö.y.), 2017

Noriko Kuresumi, New York'ta yaşayan, okyanusun uyumu ve dengesinden esinlenen zarif, şehvetli formlarla seramik heykeller üreten bir Japon sanatçıdır. Metropolde yaşadığı için doğayla baş başa olabileceği zamanları değerlendirdiğini ifade eden Kuresumi, bazen rahatlamak için kendini doğada bulduğunu söyler. Her sabah kendiyle olumlu bir sohbette bulunarak, bundan ilham aldığını düşünmektedir. Bazen ay ile kurduğu ilişkiden ilham aldığını da söylemektedir. Sanatçının eserlerinde porselen çamuru tercih etmesinin sebebi, bu malzemede kadınsı bir şıklık görmesindendir. Sanatçı porselen çamur bünyesinin olanaklarını, Ay'ın dünya üzerindeki etkisiyle benzeştirir. Aynı zamanda sanatçı, okyanusu izlemeyi sevdiğini, okyanusun duygularını yansıtabildiğini vurgular. Sanatçı, denizden ilham aldığ biyolojik formlarla çalışır. Ona göre, deniz yaşamın kökenidir. Tüm yaşamların birbirine bağlı olduğunu ve birbirlerini desteklediğini düşünmektedir. Çalışmalarını okyanusun uyum ve dengesinin kaynağını hayal ederek yaratmaktadır. Okyanusu Dünya'nın annesi olarak nitelendirir. "Denizin belleği" adlı sergisinde sanatçı, doğadaki mükemmel uyumu ve birlikteliği eserlerine taşımıştır (http:6). 


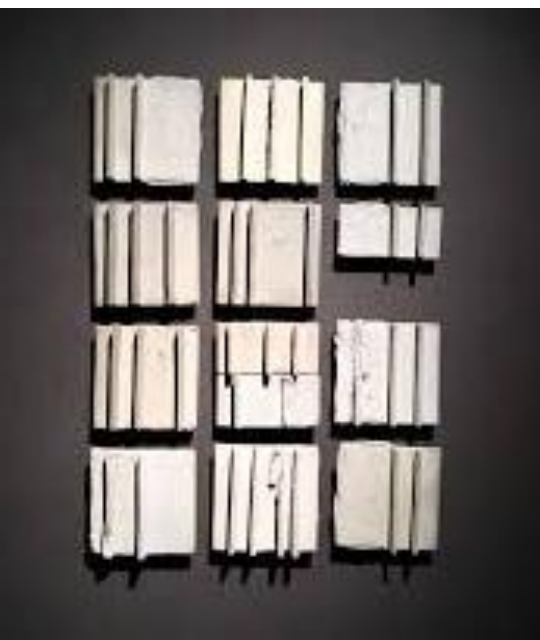

(25)

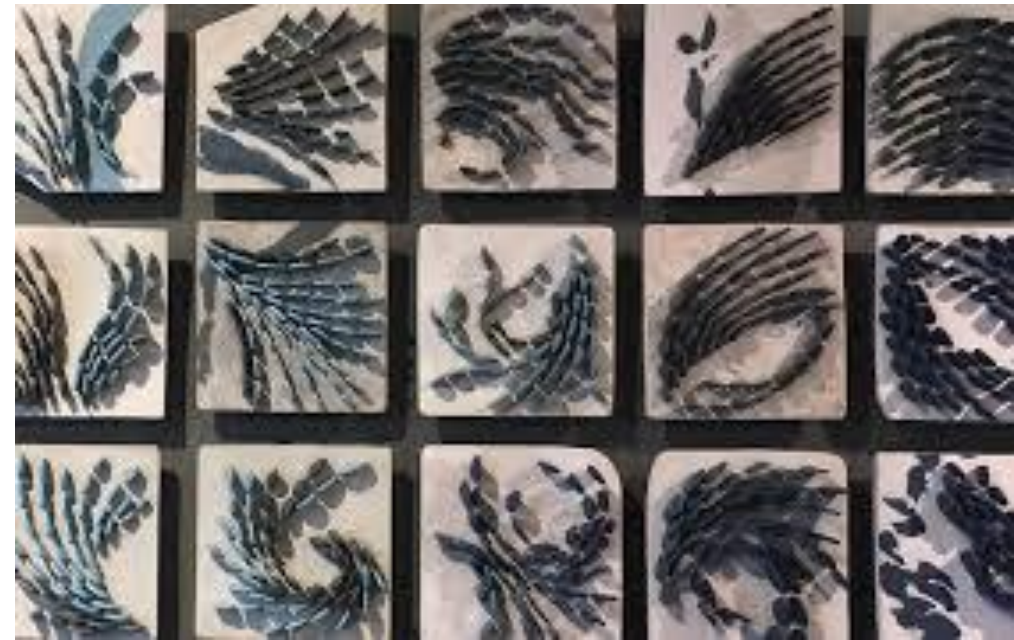

(26)

Görsel (25). Rekha Goyal, "Suyun Belleği”, seramik, 50.8 x 71 cm, 2018,

Görsel (26). Rekha Goyal, "Su Duvar Panosu”, (ö.y.), 2018

Rekha Goyal, 2018'de "Su Duvar Panosu" adlı eserinde sakin bir gölden esinlenmiştir. Sanatçı, nehri, ritmik çalkantılı bir okyanusa benzetmektedir. Goyal, suyu doğanın bir gücü olarak nitelendirir. Sanatçı, su ile ilgili ruha yansıyan duygu durumlarını araştırmaktadır. Sanatçı eserlerinde ruh hallerini anlatırken ifade aracı olarak çamur malzemeyi kullanmıştır. Onun için çamur aslında ruh halinin kendisidir. Eserde her bir parça kendi hikâyesiyle benzersiz ve farklıdır. Sanatçı yapı elemanı olarak, bir nehir içindeki çakıl şeklini kullanmıştır. Eserlerinde, farklı ruh hallerini ifade etmek için suyun oluşturduğu izlere yer vermiştir.

Sanatçı suyu şöyle tanımlar: "Yaşamın olduğu yerde su var. Su her yerdedir, hatta bedenimizdedir. O olmadan hepimiz toza dönüşecektik." Sanatçı suyun, çamur için doğum ve ölüm döngüsünü tamamladığını düşünmektedir. Sanatçı çalışmasında su belleği, su ile çamur arasındaki temel yaratma ve yıkım ilişkisini vurgulamaktadır. Çünkü su; toprak malzemenin pişirilmesiyle birlikte artık seramik bünyede yer almamaktadır fakat hafızasında yer almaya devam etmektedir (http:7).

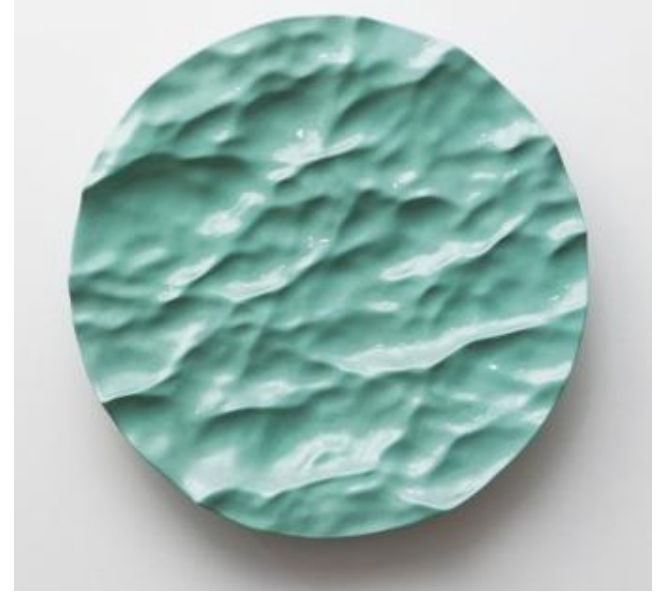

(27)

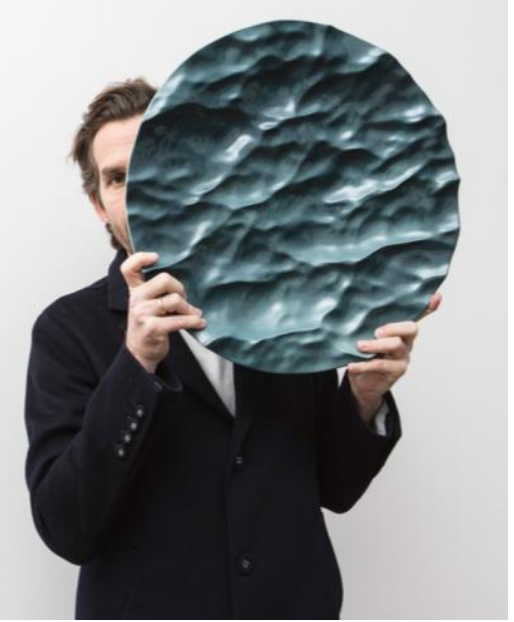

(28)

Görsel (27), (28). Mathieu Lehanneur, "50 Deniz Sergisi”, yarıçap 50 cm, 2018

Fransız tasarımcı Mathieu Lehanneur "50 Deniz sergisinde”, Gine Körfezi'nden Hudson Körfezi'ne, Antartika'nın Wededell Denizi'nden Bengal Körfezi'ne kadar 50 farklı denizin topolojisini seçerek, dünyanın sıvı ortamının küresel renk şemasını kristalize etmiştir. Bunu yapmak için sanatçı, yüksek tanımlı uydu fotoğrafçılığı kullanmış, dünyadaki elli noktayı tespit etmiş ve onları büyük seramik çemberlerin içine yerleştirmiştir. Lehanneur, "Gözlerimizi ve zihnimizi, eşyaların belirsizliğine 
alıştırmak zorundayız" demektedir. Söz konusu "50 Deniz sergisi” için ürettiği seramik eserlerde, seçtiği 50 farklı renk tonuyla renklendirme yapmıştır. Sergilenen her parça, ortamının coğrafi özelliğini taklit etmek için benzersiz bir biçimde tasarlanmıştır.

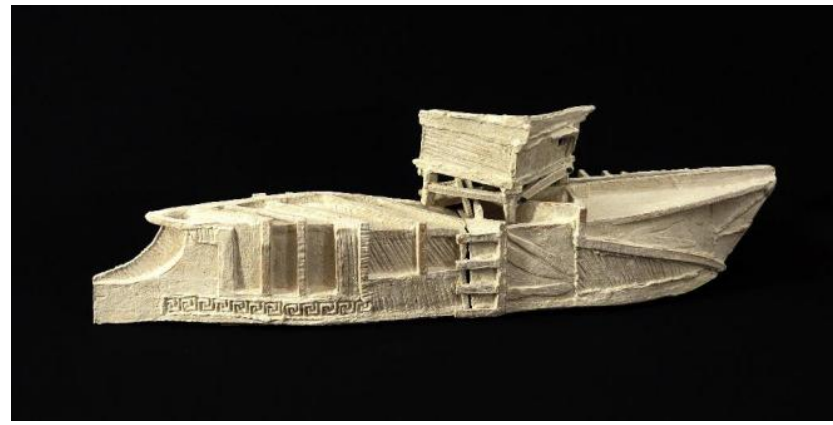

Görsel 29. Fatih Karagül, Trireme (Agamemnon), Pekişmiş çini ve porselen, g. 66 cm, 2018

Deniz ulaşımı yüzyıllar boyunca önemli bir bellek aracı olmuş, bir çok sanatçıların da bu alanda üretime kaynaklık etmiştir. Eski Çağlarda gemiler aracılığıyla kültürel aktarımın gerçekleştiği gibi, salgın hastalıklar, pek çok savaşlar gibi olumsuzlukların da gemiler aracılığıyla gerçekleştiği görülmektedir. Fatih Karagül'de deniz kentinde yaşaması ve yaşadığı ülkenin üç tarafının denizlerle kaplı olması ve yaşadığı coğrafyanın tarihi geçmişi, mitolojisinden yola çıkarak sıklıkla gemi temasını eserlerinde kullanmıştır. Sanatçı yerel unsurları tema edinerek biçimsel olarak eserlerinde kullanmıştır. Yaşadığı kentin kültüründen esinlenerek İlyada ve Odesya da yer alınan gemiler, geleneksel Çanakkale gemileri ve şehrin gemicilik faaliyetleri sanatçının eserlerine esin kaynağı olmuştur (Korkmaz, 2018, s.1532).

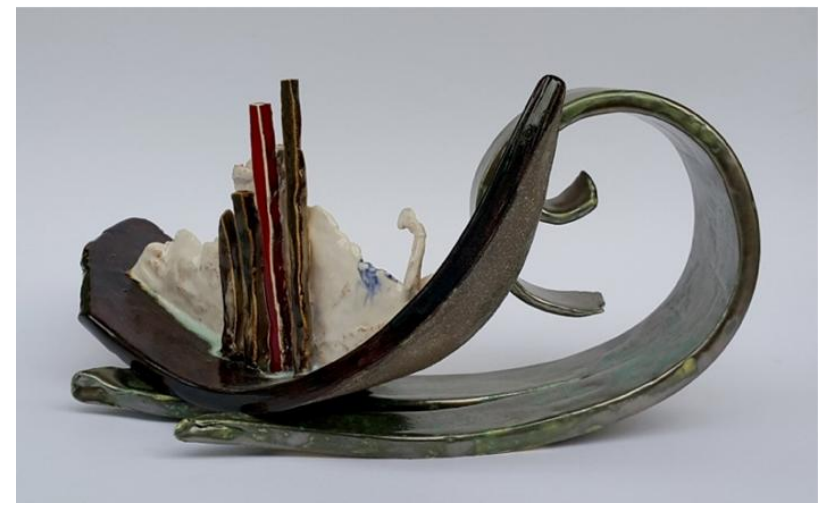

Görsel 30. Tuba Korkmaz, “Odysseus'un Gemileri”, 45x27x29 cm, 2018

Tuba Korkmaz da eserlerinde yasadığ ş̧ehrin külturünden ilham alarak eserlerinde gemi formu kullanan bir diğer santçı. 2018 yılında, Çanakkale Devlet Güzel Sanatlar Galerisi'nde Odysseus'un Gemileri 'Troia'dan Ithaka'ya Yolculuk' adlı sergisini açmıştır. Serginin konusu Truva savaşı sonrasında evi Ithaka'ya dönmek üzere 12 gemi ile birlikte yola çıkan Odysseus'un yolculunun anlatıldığı Homeros'un etkileyici eseri Odysseia'dır (Korkmaz, 2018, s.1533). Sergide bahsi geçen 12 gemi figürü imgesel olarak ele alınmıştır. 


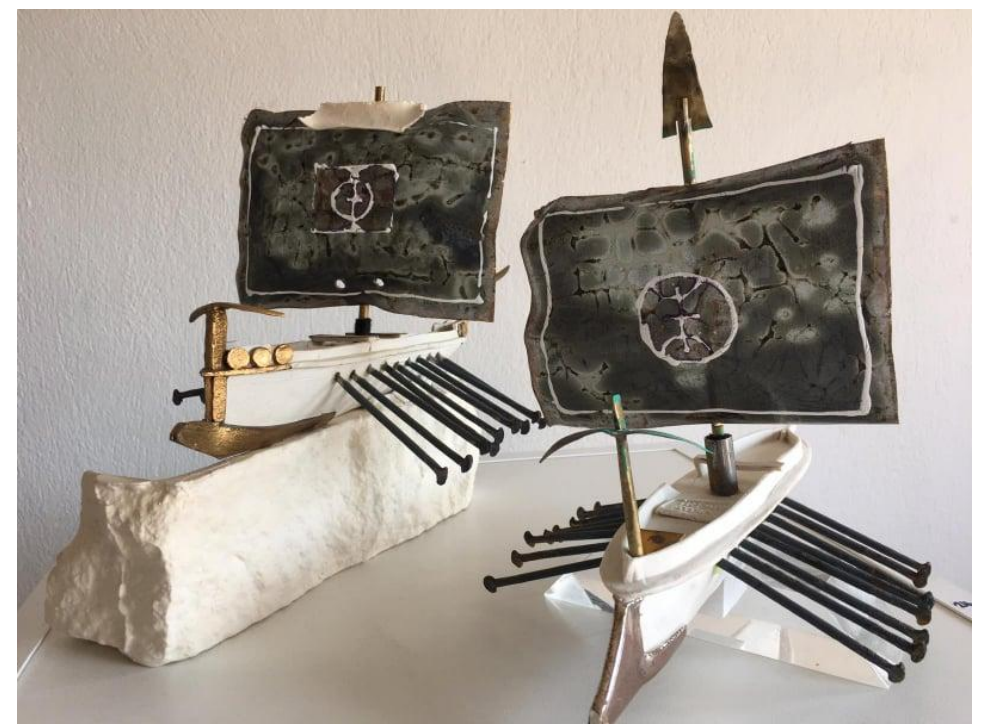

(31)

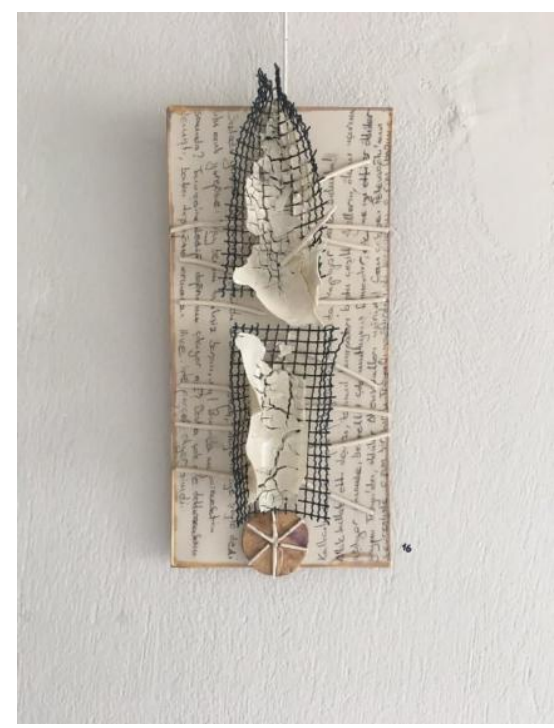

(32)

Görsel (31), (32). İrfan Aydın, “Deniz, Renk, Doku, Dokunuşlar” sergisinden, (ö.y.), 2019

Eserlerinde su imgesine yer veren sanatçılar arasında yer alan İrfan Aydın'ın 2019 yılında açtı̆̆ “Deniz, Renk, Doku, Dokunuşlar" isimli sergisinde yer alan eserlerinin çıkış noktası denizdir. Fakat deniz tam olarak sanatçının anlatmak istediği şeyi ifade etmemektedir. Sanatçının bahsetmek istediği su ve suyun hafızasıdır. Daha doğrusu sanatçı, metaforik olarak su ve denizi aynı kategoride ele almaktadır. Sanatçının ifadesiyle deniz, üzerinde binlerce yıldır gemilerin gelip geçtiği bir mekândır. Sanatçı, özellikle yaşadığı toprakların kıyısında bulunan Akdeniz'den etkilenmiş ve hikâyelerinde onun üzerinden yola çıkmışıtır. Aydın, uzun yıllar arkeolojik kazılarda bulunmuş ve orada yaşadıklarından çok etkilenmiş, eserlerinde antik dönemdeki denizi ve denizle olan ilişkileri ele almıştır. Sanatçı, denizin bir hafizası olduğu düşüncesinden yola çıkmıştır. Sanatçı zaman içinde eserleriyle birlikte batık gemilere yeni hikâyeler yazmış ve onları yeniden canlandırmıştır. Sanatçı Marmaray kazıları esnasında çıkan batıkları incelemiş, bölgeden çıkan kalıntıların kille kaplı olduğunu görmüş ve bu durumdan çok etkilenmiştir. Çok uzun yıllar bu kalıntıların günümüze kadar gelmesine yardımcı olan bu killeri, sanatçı özel bir izinle almış ve kendi eserlerinde kullanmıştır (Aydın, Röportaj, 2019).

\section{SONUÇ}

$\mathrm{Su}$, insanlık tarihinde önemli bir yere sahiptir. Bununla birlikte birçok alanda olduğu gibi seramik sanatındaki yeri de oldukça mühimdir. Toprağın şekillendirilebilmesi için muhakkak suya ihtiyaç vardır. $\mathrm{Bu}$ yönüyle su, seramiğe hayat veren unsurlar arasındadır. Özellikle eski Çağlarda, henüz cam vb. materyaller yokken seramik; sıvı ve katı ürünlerin taşınmasında önemli bir malzeme olarak karşımıza çıkmaktadır. Her iki durum da seramik ile su arasında özel bir ilişki kurulmaktadır. Bütün canlıların ortak ihtiyacı olan su, yaşam devam ettiği sürece en önemli kaynaklardan biri olmaya da devam edecektir. Günümüzde suyla kurulan ilişkiye bakıldığında canlı yaşamı için temel madde olan su, maalesef gittikçe ulaşılması güç bir kaynağa dönüşmektedir. Seramik sanatçıları için suyun önemi, sanatçı eserlerinde görüldüğü gibi farklı şekillerde yansımaktadır. Suya verilen anlam, ilk Çağlardan bu yana aynı şekilde süregelmektedir. Sanatçılarla birlikte suyun çeşitli imgeleri kişilerde su ile ilgili farklı açılımlar yaratmaktadır. Canlılar için hayati önem taşıyan bu maddenin farkındalığı, eserler aracılığıyla tekrar gündeme gelmektedir. Eserler incelendiğinde sanatçıların çoğunlukla suyun hareketinden ve renginden etkilenerek formlarına yansıttıkları görülmektedir. İnsan hayatındaki izleri son derece derin olan suyun, gelecek dönemlerde de etkisini arttırarak sanatta önemli bir imge olarak kullanılacağı düşünülmektedir. 


\section{KAYNAKÇA}

Ateş, E. (2014). Kültepe kalıntıları ve kil tabletler. Hacettepe Üniversitesi Edebiyat Fakültesi, Anadolu Uygarlıkları ve Sanat1, Sanat Tarihi 1. 1 Haziran 2019 tarihinde https://www.academia.edu/12843741/K\%C3\%BCltepe $\mathrm{Kal} \% \mathrm{C} 4 \% \mathrm{~B} 1 \mathrm{nt} \% \mathrm{C} 4 \% \mathrm{~B} 1 \mathrm{lar} \% \mathrm{C}$ 4\%B1 adresinden erişildi.

Avşar, Z.\& Avşar, S. (2016). Var olmanın ve arınmanın tarihi seyri içerisinde bedensel - ruhsal temizlik mekânları olarak hamamların iletişim bakımından önemi. İdeal Kent Araştırmaları Dergisi, 7(19), 628-658.

Aydın, H. (2004). Pavilion of the sacred relics the sacred trusts / Topkapı Palace Museum. İstanbul: Kaynak Kitaplığ 1

Bachelard, G. (2006). Su ve düşler maddenin imgelemi üzerine deneme. İstanbul: YKY

Barlow, M. (2016). Su hakkı. İstanbul: Yeni İnsan Yayınevi

Burnett, R. (2012), İmgeler nasıl düşünür?İstanbul: Metis Yayınları

Cevizci, A. (2000). Paradigma felsefe terimeri. Çanakkale: Paradigma Yayınları

Connerton, P. (2011). Modernite nasll unutturur? İstanbul: Sel Yayınları

Draaısma, D. (2014). Bellek metaforları, zihinle ilgili fikirlerin tarihi. İstanbul: Metis Yayınları

Eliade, M. (2017). Imgeler ve simgeler. Ankara: Doğubatı Yayınları

Erdan, E. (2015). Demir çağ ve sonrası Batı Anadolu'da Frig kültür etkileri. Yayımlanmamıs doktora tezi. Adnan Menderes Üniversitesi Sosyal Bilimler Enstitüsü Arkeoloji Anabilim Dal,, Denizli.

Foucault, M. (2002). Bu bir pipo değildir. çev. Selahattin Hilav. İstanbul: YKY.

Gordon, Z. M. (2013). Hikaye anlatan su oyunları. Yayımlanmamış yüksek lisans sanat çalışması raporu, Hacettepe Üniversitesi Güzel Sanatlar Enstitüsü Seramik Anasanat Dalı, Ankara.

Gökbel, F. M. (2019). Hamam kültürü ve seramik yansımaları. Atatürk Üniversitesi Güzel Sanatlar Enstitüsü Dergisi, 43, 57-68.

Karagül, F. (2018). Yerel değerlerin sanatta esin kaynağı olarak kullanimina bir örnek: Troia sergisi. Journal of Awareness, 3, 119-126.

Korkmaz, T. (2018). Çağdaş seramik eserlerde gemi formu. Ulakbilge, 6(30), 1523-1536.

Küçükaşc1, M.S. (2017/2). Zemzem. Z’Kültür/Sanat/Şehir, 74-79.

Sadberk Hanim Museum (1996). İstanbul: Tanım Yayıncılık ve Danışmanlık.

Sartre, J. P. (2017). Imgelem. İstanbul: İthaki Yayınları.

Tutor, Z. P. (2011). Kendi: The characteristic vessel of bagan period. Submitted to Myanma Academy of Arts and Science, Department of Archaeology Dagon University.

\section{INTERNET KAYNAKLARI}

1. Su. 22 Ocak 2019 tarihinde https://www.britannica.com/science/water adresinden erişildi.

2. 23 Ocak 2019 tarihinde http://www.karalahana.com/2018/02/10/women-from-prehistory-to-the-ironage/ adresinden erişildi.

3. Globe, N. 19 Temmuz 2019 tarihinde http://nickolaiglobe.com adresinden erişildi.

4. Machiko, O. 14 Ağustos 2019 tarihinde https://www.artsy.net/artwork/machiko-ogawa-fragment adresinden erişildi. 
5. Tanoue, S. 27 Eylül 2019 tarihinde https://www.mizenfineart.com/en/exhibition-_paris/tanoue_shinya/ adresinden erişildi.

6. Kokuresumi, N. 1 Ağustos 2019 tarihinde http://www.norikokuresumi.com adresinden erişildi.

7. Goyal, R. 2 Ekim 2019 tarihinde https://www.rekhagoyal.com/the-memory-of-water-ceramicinstallation adresinden erişildi.

8. Lehanneur, M. 25 Eylül 2019 tarihinde https://www.designboom.com/design/mathieu-lehanneur-50seas-exhibition-christies-paris-01-18-2018/ adresinden erişildi.

9. Goethe. 25 Ağustos 2019 tarihinde http://www.kuts.com.tr/assets/mailing/newsletter/2015/Ekim2015Mailingi.pdf christies-paris01-18-2018/ adresinden erişildi.

10. Uras, E. 21 Ağustos 2019 tarihinde http://www.elifuras.com/ adresinden erişildi.

\section{RÖPORTAJ}

Güngör Güner, 30/08/2019

İrfan Aydın, 25/9/2019

\section{GÖRSEL KAYNAKÇASI}

Görsel 1. Sadberk Hanim Museum (1996). s.10.

Görsel 2. Sadberk Hanim Museum (1996). s.24

Görsel 3. 24 Ocak 2019 tarihinde https://www.flickr.com/photos/galpay/4227576479/in/photostream/ adresinden erişildi.

Görsel 4. Ateş, E. (2014).

Görsel 5. 24 Ocak 2019 tarihinde http://collections.vam.ac.uk/item/O179521/kendi-unknown/ adresinden erişildi.

Görsel 6. 23 Ocak 2019 tarihinde https://www.proantic.com/en/display.php?mode=obj\&id=397525 adresinden erişildi.

Görsel 7, 8. Gedük, S. Zemzem ve Topkapi Sarayi Müzesi Zemzem Şişeleri. 3. Sağl1k Tarihi ve Müzeciliği Sempozyumu, 19-21 Mayıs 2017, s.107-118

Görsel 9. Fokus Dergisi/ Kasım-Aralık 2014, s. 52

Görsel 10. Gordon, Z. M. (2013).

Görsel 11,12. Güngör Güner Kişisel Arşiv

Görsel 13,14. Gordon, Z. M. (2013).

Görsel 15,16. 19 Temmuz 2019 tarihinde http://nickolaiglobe.com adresinden erişildi.

Görsel 17,18. 14 Ağustos 2019 tarihinde https://www.artsy.net/artist/machiko-ogawa adresinden erişildi.

Görsel 19. 21 Eylül 2019 tarihinde http://www.elifuras.com/ adresinden erişildi.

Görsel 20. Anikya İznik Çini, Mimari Kataloğu, s.19

Görsel 21, 22. 21 Ağustos 2019 tarihinde https://www.mizenfineart.com/en/exhibition_paris/tanoue_shinya/ adresinden erişildi.

Görsel 23, 24. 11 Ağustos 2019 tarihinde www.norikokuresumi.com adresinden erişildi.

Görsel 25, 26. 11 Ağustos 2019 tarihinde https://www.rekhagoyal.com/the-memory-of-water-ceramicinstallation adresinden erișildi.

Görsel 27, 28. 19 Ağustos 2019 tarihinde https://www.designboom.com/design/mathieu-lehanneur-50seas-exhibition-christies-paris-01-18-2018/ adresinden erişildi. 
Görsel 29. Karagül, F. (2018).

Görsel 30. Korkmaz, T. (2018).

Görsel 31, 32. İrfan Aydın Kişisel Arşiv 